\title{
Nutrient contents and in vitro digestibility of different parts of corn plant
}

\author{
T. Ayaşan ${ }^{1 \#, ~ N . ~ C e t i n k a y a ² ~}{ }^{2}$ S. Aykanat ${ }^{3}$ \& C. Celik $^{2}$ \\ ${ }^{1}$ Osmaniye Korkut Ata University, Kadirli Academy of Applied Sciences, Osmaniye, Turkey \\ ${ }^{2}$ Ondokuz Mayis University, Faculty of Veterinary Medicine, Department of Animal Nutrition and Nutritional Diseases. \\ 55139, Atakum, Samsun, Turkey \\ ${ }^{3}$ East Meditarrenean Agricultural Research Institute, Adana, Turkey
}

(Received 16 March 2020; Accepted 7 April 2020; First published online 18 May 2020)

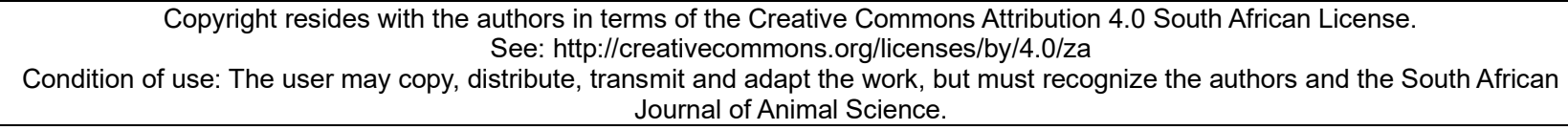

\begin{abstract}
The objective of this study was to assess the nutrient contents and in vitro true digestibility (IVTD) of parts of the corn plant. The corn used in the study was P2088, a variety that is grown widely in Turkey. It had matured and was harvested 140 days after planting. Four replicate plants were separated into nine parts, namely lower stalk, central stalk, upper stalk, corn ear stalk, corn ear shuck, kernels, corn cob, leaf, tassel, plus the entire plant. The samples were dried and ground for analysis. Nutritional values were determined in the laboratory and in vitro digestibility was assessed. Significant differences in nutrient content were observed among parts of the corn plant. The highest crude protein (CP) content was found in the leaf $(12.41 \%)$, followed by the grain $(12.37 \%)$. Dry matter (DM) varied from $91.25 \%$ to $96.07 \%$. The highest ether extract (EE) was in the grain $(2.84 \%)$, and the upper stalk contained the least $E E(0.29 \%)$. The parts also differed in their contents of crude cellulose (CS) and crude ash (CA) $(P<0.001)$. Most organic matter (OM) was found in the corn cup $(94.27 \%)$. The highest in vitro dry matter digestibility (IVDMD) was in the kernels $(79.06 \%)$ and the lowest was in the lower stalk (38.13\%). In terms of in vitro true organic matter digestibility $(\mathrm{OMD})$ values of the corn plant and its 9 parts, the highest values were found in the kernels and the lowest in the lower stalk.
\end{abstract}

Keywords: crude nutrients, in vitro true digestibility, parts of corn plant

\#Corresponding author: tayasan@gmail.com

\section{Introduction}

Quality roughage and concentrate feeds are the most important input in livestock farming, so there is a need for procuring this feed, increasing its production, and meeting the requirements of the livestock industry. Feed prices are a major factor that affects the economic viability of farmers. Therefore, efforts dedicated to reducing feed costs would be of direct benefit to them IN this regard, using corn residues after harvest is one practice that reduces feed expenses, and lowers the cost of animal production.

Corn, an annual warm-season cereal crop, can be grown in tropical, subtropical, and temperate climate zones. It occupies $25.7 \%$ of the land area that is used in cereal cultivation (Açar et al., 2015). Although it is used primarily as human food and animal feed (Tandzi \& Mutengwa, 2020), corn is an industrial raw material. It has particular importance in human nutrition in less developed countries. Cereal grain production totals 2.7 billion tons worldwide, of which corn amounts to 1038281 thousand tons or $38.1 \%$ of total cereal production. Corn ranks third after wheat and rice in cultivation area and first in the amount produced in the world. In Turkey, grain corn and corn silage account for $68 \%$ and $32 \%$ of the area planted to corn, respectively (Turkish Grain Board, 2014).

The kernels constitute approximately $46 \%$ of the dry matter of a corn plant, with the stalk, leaf, cob and husk collectively constituting the remaining 54\% (Pordesimo et al., 2004). Kowalik et al. (2013) stated that the DM, chemical composition and energy values for the corn stalk differed, depending on the variety and the cutting height of the plant at harvest. Corn stover (stalk and leaf) can be used effectively in ruminant feeding (Li et al., 2014; Feedipedia, 2016; Mourtzinis et al., 2016). 
Studies on the nutrient analysis and in vitro digestibility of the parts of corn are scarce in the scientific literature. Therefore, this study was designed to examine the variations in nutrient composition of the ten parts that make up the corn plant using in the vitro gas production technique.

\section{Materials and Methods}

Rumen fluid for use in measuring in vitro digestibility was collected at Florya Company Slaughter House (Samsun, Turkey) from freshly slaughtered animals. These beef cattle had been kept for commercial meat production at Florya Company's farm. They were fed dried grass (83 g CP/kg DM; 6 MJ ME/kg DM) ad libitum and $8 \mathrm{~kg}$ concentrate feed (120 g/kg CP and $10.80 \mathrm{MJ}$ ME/kg DM). Immediately after collection, the rumen fluid was transported to the Ruminant Feed Evaluation Laboratory. Ruminal content was strained through three layers of cheesecloth and kept at $39{ }^{\circ} \mathrm{C}$ in a $\mathrm{CO}_{2}$ atmosphere until it was used in an in vitro digestibility assay.

Table 1 Chemical analysis of soil samples collected from corn fields at Dogankent

\begin{tabular}{|c|c|c|c|c|c|c|c|c|c|c|c|}
\hline \multirow{2}{*}{ Saturation, \% } & \multirow{2}{*}{ Soil type } & \multirow{2}{*}{$\mathrm{pH}$} & Salt & Lime & $\mathrm{OM}$ & $\mathrm{P}_{2} \mathrm{O}_{5}$ & $\mathrm{~K}_{2} \mathrm{O}$ & $\mathrm{Zn}$ & $\mathrm{Fe}$ & $\mathrm{Cu}$ & $\mathrm{Mn}$ \\
\hline & & & \multicolumn{5}{|c|}{ kg/dekare } & \multicolumn{4}{|c|}{$\mathrm{mg} / \mathrm{kg}$} \\
\hline 72 & Clayey & 8.10 & 0.02 & 15.96 & 2.38 & 4.69 & 150.97 & 0.35 & 7.28 & 1.23 & 4.86 \\
\hline
\end{tabular}

OM: Organic matter, $\mathrm{P}_{2} \mathrm{O}_{5}$ : phosphorus pentoxide, $\mathrm{K}_{2} \mathrm{O}$ : potassium oxide, $\mathrm{Zn}$ : zinc, Fe: iron, Cu: copper, Mn: manganese

During the corn growing season, $155.6 \mathrm{~mm}$ of precipitation were received. Seasonal climate values of main product corn are shown in Table 2. Because of insufficient precipitation, drip irrigation was provided once a week during the growing season and for ten times in total. The weather temperature values in the first half of June did not affect pollination negatively. That is, the kernel set, and seeds extended the full length of the cob. In short, during the fertilization weeks, there was an ideal climate for the corn. The highest average value for relative humidity was observed in June at $76.27 \%$. Relative humidity increased with temperature and irrigation of the crop. This created an environment that was conducive to the emergence of fungal diseases, but chemical treatments were not carried out because the severity of the northern leaf blight and rust diseases was below the economic damage threshold.

Table 2 Weather during the growing season for corn at Dogankent from 27 March to 13 August 2018

\begin{tabular}{|c|c|c|c|c|c|c|c|c|}
\hline \multirow{2}{*}{ Month } & \multirow{2}{*}{ Days } & \multicolumn{3}{|c|}{ Air temperature, ${ }^{\circ} \mathrm{C}$} & \multicolumn{3}{|c|}{ Relative humidity, \% } & \multirow{2}{*}{$\begin{array}{l}\text { Rainfall, } \\
\mathrm{mm}\end{array}$} \\
\hline & & Minimum & Maximum & Mean & Minimum & Maximum & Mean & \\
\hline March & 5 & 10.4 & 24.78 & 17.04 & 33.18 & 94.38 & 68.68 & 18.80 \\
\hline April & 30 & 13.00 & 27.93 & 19.90 & 35.06 & 96.88 & 69.49 & 44.20 \\
\hline May & 31 & 16.81 & 31.10 & 23.20 & 36.82 & 95.43 & 70.36 & 80.6 \\
\hline June & 30 & 19.68 & 32.29 & 25.36 & 46.08 & 98.10 & 76.27 & 11.4 \\
\hline July & 31 & 22.54 & 34.08 & 27.89 & 47.57 & 97.07 & 75.76 & 0.60 \\
\hline August & 13 & 23.04 & 35.02 & 28.37 & 44.47 & 96.24 & 74.30 & 0.00 \\
\hline Total & 140 & & & & & & & 155.6 \\
\hline
\end{tabular}

The production area was tilled to make it ready for sowing. Ridges, $70 \mathrm{~cm}$ apart, that had been created in the autumn were tilled again in January because of weed growth. Just before sowing, the base dressing was applied, and the ridges were prepared for planting. The corn planter was adjusted to ensure a planting depth of $5-6 \mathrm{~cm}$ and seeds were spaced $20 \mathrm{~cm}$ apart on the ridges. Germination was completed 15 days after 
planting. Diammonium phosphate fertilizer was applied at $22.5 \mathrm{~kg} /$ dekare during planting and $67.5 \mathrm{~kg}$ urea/dekare was applied as a top dressing when the plants were $40-50 \mathrm{~cm}$ tall.

The plants were first cultivated for weed control when they reached the height of $10-15 \mathrm{~cm}$, and again when they reached a height of $40-50 \mathrm{~cm}$. During the corn growing season, a pesticide was used once for protection from corn borers. Immediately after being cultivated for the second time, a drip irrigation system was installed, and the plants were watered. Irrigation continued once a week for the remainder of the growing season.

The corn reached harvest maturity after 140 days and was harvested on 13 August 2018. Four randomly selected replicate plant samples were collected. These plant samples were separated into nine parts (Figure 1), and the fractions were dried and ground for nutrient analyses.

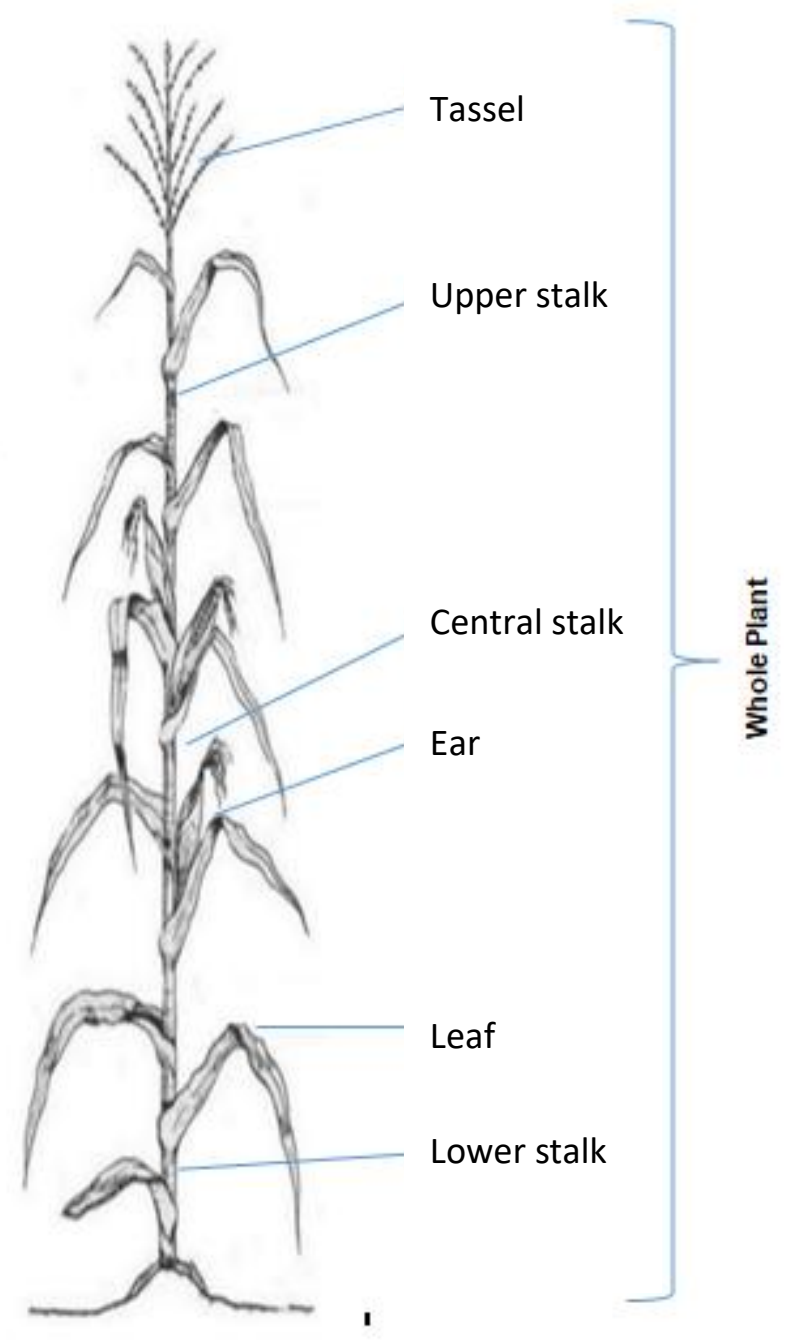

Figure 1 Morphological schematic of a corn plant illustrating its parts

The total corn plant and lower stalk, central stalk, upper stalk, corn ear stalk, corn ear shuck, kernels, corn cob, leaf, tassel of the corn plant were sampled. There were four replicate samples from the total plant and each of the nine parts were analysed individually. Samples were milled to pass through a 1-mm sieve. Milled feed samples were then analysed chemically using AOAC methods for dry matter (DM), crude protein (CP), ether extract (EE), crude cellulose (CC), and crude ash (CA) (AOAC, 2006). An in vitro Ankom Daisy fermentation device (Ankom Technology Corp. Fairport, NY, USA) was used to estimate the true digestibility of samples of corn plant and each of its ten parts. Again, the quadruple samples from each part of the plant were used to estimate IVTD. The method of determining IVTD was described by Czerkawski and 
Breckenridge (1977). Buffer solutions were prepared as specified for Ankom Daisy in vitro fermentation equipment

The weighed sample bags were placed in four digestion jars. Then $1600 \mathrm{~mL}$ buffer solution and 400 $\mathrm{ml}$ rumen fluid were poured into each jar. The jars were removed from their chambers after 48 hours of incubation at $39^{\circ} \mathrm{C}$. Bags were rinsed with cold running tap water, then dried at $105^{\circ} \mathrm{C}$ for 12 hours and burned in an ashing oven at $550{ }^{\circ} \mathrm{C}$ for $4-6$ hours. The DM and ash contents of each sample were calculated. Finally, in vitro true digestibility (D) was calculated for DM and OM using the equation given by Ozcan and Kiliç (2018):

Where: $\mathrm{W} 1=$ weight of $\mathrm{F} 57$ bag,

$$
D=100-\frac{((W 3-(W 1 x C 1))}{W 2}
$$

$\mathrm{W} 2=$ dried sample or nutrient $(\mathrm{DM}$ or $\mathrm{OM})$,

W3 = nutrient left in residue after incubation, and

$\mathrm{C} 1=$ weight of blank bag after incubation.

Analysis of variance was used to test differences among parts of the corn plants. Duncan's multiple comparison test was used to separate means when significant differences were observed.

\section{Results and Discussion}

In Çukurova region, the early maturing (105 - 115-day) varieties (FAO 650-750) are preferred as the main crop and the 120 - 135-day varieties (FAO 550-650) are considered a secondary crop (FAO, 2014). If the corn is sown as the main crop, it is the best to sow it between March and mid April. If it is the secondary plant, it should be sown immediately after the wheat harvest and by the beginning of July at the latest. In both cases, the harvest time is between late September and early October.

Corn kernels are commonly used in animal feeding as a source of energy (Li et al., 2014). On the top of the stalk of corn, there are male flowers in the shape of a mixed cluster (tassel). Female flowers grow in the shape of an ear in the axil on the middle part of the stalk. Each plant has one to three ears. A corn plant produces three to five million pollen grains. Blooming starts on the tassel one to three days before the silk grows out. Almost immediately after coming into contact with the silk, pollen grains start the growth of the pollen tube, which ultimately enters the female flower or ovule. Each ovule is a potential kernel and a welldeveloped ear should have 750 - 1000. Li et al. (2014) stated that the tassel consisted of $92.26 \% \mathrm{DM}, 6.60 \%$ $\mathrm{CP}, 1.4 \% \mathrm{CF}, 71.49 \% \mathrm{NDF}, 37.80 \% \mathrm{ADF}$, and $5.78 \% \mathrm{ADL}$. All chemical constituents varied among the parts of the corn plant $(P<0.001)$. The chemical compositions of the entire corn plant and its parts are shown in Table 3.

Table 3 Chemical composition of total corn plant and its ten parts

\begin{tabular}{|c|c|c|c|c|c|}
\hline Parts & DM \% & CP \% & EE \% & CF \% & $C A \%$ \\
\hline Lower stalk & $94.05^{b c}$ & $6.05^{c}$ & $0.41^{\mathrm{de}}$ & $38.96^{a}$ & $5.31^{\text {de }}$ \\
\hline Central stalk & $92.92^{\mathrm{cd}}$ & $6.30^{c}$ & $0.43^{\mathrm{de}}$ & $29.23^{\text {cde }}$ & $5.14^{\text {de }}$ \\
\hline Upper stalk & $91.61^{\mathrm{de}}$ & $4.37^{\mathrm{d}}$ & $0.29^{e}$ & $29.61^{c d}$ & $6.88^{\mathrm{c}}$ \\
\hline Ear stalk & $92.73^{\mathrm{cd}}$ & $5.03^{\mathrm{cd}}$ & $0.56^{\text {cde }}$ & $27.04^{\mathrm{e}}$ & $4.70^{\mathrm{e}}$ \\
\hline Ear shuck & $95.13^{\mathrm{ab}}$ & $4.30^{d}$ & $0.79^{b c}$ & $32.32^{b}$ & $6.03^{\mathrm{cd}}$ \\
\hline Kernels & $92.56^{\text {de }}$ & $12.37^{a}$ & $2.84^{a}$ & $2.60^{\mathrm{g}}$ & $0.82^{\mathrm{g}}$ \\
\hline Cob & $96.07^{a}$ & $4.00^{d}$ & $0.31^{\text {de }}$ & $32.50^{\mathrm{b}}$ & $1.80^{\dagger}$ \\
\hline Leaf & $92.80^{\mathrm{cd}}$ & $12.41^{\mathrm{a}}$ & $1.03^{b}$ & $22.17^{f}$ & $17.90^{\mathrm{a}}$ \\
\hline Tassel & $91.25^{\mathrm{e}}$ & $11.03^{\mathrm{a}}$ & $0.60^{\text {cd }}$ & $30.32^{b c}$ & $10.86^{b}$ \\
\hline Entire plant & $92.22^{\mathrm{de}}$ & $9.03^{b}$ & $0.40^{\mathrm{de}}$ & $27.84^{\mathrm{de}}$ & $5.02^{\mathrm{e}}$ \\
\hline
\end{tabular}

${ }^{\mathrm{a}-\mathrm{e}}$ within columns means with a common superscript do not differ at $P=0.05$

DM: dry matter, CP: crude protein, EE: ether extract, CF: crude fibre, CA: crude ash

With the development of silage technology, the entirety of the corn plant has become one of the most important feedstuffs for animals in the world. 
Corn stalk is generally classified as low-quality roughage. In recent years, it has emerged as a competitor to corn straw. It has become a product and is baled, not left on the field. The main problem with the use of corn stalks in animal feeding is their physical condition. Before giving them to animals as feed, they should be chopped and added to the total mixed ration (TMR). Ming-yuan et al. (2015) found that the DM content of the lower stalk, middle stalk, and top stalk were $79.1 \%, 73.7 \%$, and $64.0 \%$, respectively, and the DM content of the whole stalk was $75.7 \%$. Ayaşan et al., (2019) found that DM contents were $90.92 \%$, $91.54 \%$, and $90.54 \%$, respectively, with an average of $91.00 \%$. In another study, it was found that the nutrient contents of corn stalks differed depending on the levels of added enzyme. The structure of the corn stalk without enzyme additive contained $87.90 \%$ DM, 2.02\% CF, 35.06\% CC, 61.63\% NDF, 43.16\% ADF, and $9.79 \%$ ADL (Gado et al., 2017).

In the present study, the leaf contained $92.80 \%$ DM, $12.41 \% \mathrm{CP}, 1.03 \% \mathrm{CF}, 22.17 \% \mathrm{CC}$, and $17.90 \%$ CA. However, Ayaşan et al. (2019) found that the leaf contained $87.76 \%$ DM, 13.09\% CP, 66.98\% NDF, $40.87 \%$ ADF, and $0.88 \%$ ADL.

The DM content varied significantly among the morphological structures of the corn plant. Dry matter content was highest in the cob with $96.07 \%$ and lowest in the tassel with $91.25 \%$. Ndukwe et al. (2015) found the DM ratio of corn was 88.62 - 90.15\%, Ayaşan et al. (2019) found the DM ratio in seven parts of corn was $87.76-91.54 \%$. Ayaşan et al. (2019) reported that the top stalk had the highest DM and the leaf had the lowest DM. In another study, it was found that the corn cobs contained $88.52-90.83 \%$ DM (Kanengoni et al., 2015). Based on 2015 data, Pioneer 2088 contained $85.98 \%$ DM, 7.51\% CP, 3.84\% CF, 23.47\% CC, and $1.20 \%$ CA (Variety Registration and Seed Certification Centre, 2016).

The second largest constituent of the kernel was CP. In terms of the entire plant, CP was greatest in the leaf $(12.41 \%)$ and grain $(12.37 \%)$, while the cob $(4.00 \%)$ and the husk $(4.30 \%)$ had the lowest CP. Ansah et al. (2012), Olagunju et al. (2013), and Abubakar et al. (2016) reported that the cob had $3.50 \%, 3.42 \%$, and $4.19 \% \mathrm{CP}$, respectively.

With about 6\% CP, corn stover has a higher nutritional content than most straws (Feedipedia, 2016). Daud et al. (2013) reported that the corn stalk contained $24.9 \%$ ash, $42.0 \%$ hemicellulose, $7.3 \%$ moisture and $7.3 \%$ lignin. Chea et al. (2015) found the DM, CP, OM, ash and CF ratio of corn stover was 45, 6.41, $85.12,0.35$, and $22.30 \%$, respectively. However, Terler et al. (2019) indicated that the stover percentage and DM content of corn differed significantly between varieties. Corn cob is that part of the ear that is composed of a lignocellulose biomass characterized by close intertwining of cellulose ( 45 to $55 \%$ ), hemicellulose ( $25 \%$ to $35 \%$ ), and lignin (20\% to $30 \%)$. It holds the kernels. Abubakar et al. (2016) reported that the corn cob had $2.49 \%$ ash, $33.33 \%$ cellulose, $4.72 \%$ fat, $6.00 \%$ moisture, and $4.19 \%$ protein. He et al. (2019) asserted that the corn leaves and corn stalk differed in terms of chemical composition and CP content in particular.

Another study examined the nutrient content of the whole plant and the stover of four silage corn varieties. In evaluating whole-plant corn silage, He et al. (2020) found that DM ranged from $39.7 \%$ to $50.1 \%$ and averaged $42.7 \%$, CP averaged $7.0 \%$, CA averaged $3.4 \%$, and CF, NDF, ADF, and ADL averaged $3.0 \%$, $40.1 \%, 22 \%$, and $1.5 \%$, respectively. As for the stover of these varieties DM, CP, CA, and CF were $32.9 \%$, $4.9 \%, 6.0 \%$, and $1.3 \%$, respectively, and NDF, ADF, and ADL were $70.2 \%, 42.6 \%$, and $3.2 \%$, respectively (He et al., 2020).

Ayaşan et al. (2019) reported that the CP ratio in Pioneer 2088 was within the range of $3.72-14.45 \%$. The highest CP was found in the ear, with $14.45 \%$, followed by the leaf with $13.09 \%$, and the lower stalk had the lowest CP with $3.72 \%$. Ullah et al. (2010) reported that the CP values for various corn varieties were within the range of $7.71-14.60 \%$. Ndukwe et al. (2015) found the CP content of corn was $10.72-12.33 \%$. The average CP content $(7.49 \%)$ obtained in the current study was in line with that observed $(7.31 \%)$ by Lee et al. (2014). However, it was lower than the observations (10.67-11.27\%, 9.80\%, and $8.82 \%$ ) of ljabadeniyi and Adebolu (2005), Sumbo and Victor (2014), and Kılınç et al. (2018), and greater than the ratio (7.10\%) that was reported by Vaswani et al., (2016). These discrepancies might be due to differences in variety, genotype, ecological conditions of the place where the study was carried out, and the total precipitation and temperature during the harvest time and vegetation. In previous studies, it was reported that the kernels protein content showed variation owing to the genotype, and to fertilizer applications with nitrogen (Hafez \& Abdelaal, 2015) and zinc (Dumral Çağlayan, 2015), ecological conditions (Sweley et al., 2012), whether the genotype was local (Aliu et al., 2012), line or hybrid (Khan \& Dubey, 2015), sowing time and sowing frequency (Karaşahin \& Sade, 2011), stress conditions (Ali et al., 2010), and harvest time (Kalkan \& Sade, 2009; Karaşahin \& Sade, 2011).

The greatest CF content was found in the lower stalk and the lowest in the kernel. Sumbo and Victor (2014) found the CF content of maize meal (i.e. ground kernels) was $4.50 \%$. Similarly, Amodu et al. (2014) and Vasmani et al. (2016) reported that the CF of corn kernels ranged from $6.8 \%$ to $7.6 \%$ and from $0.89 \%$ to $2.07 \%(1.64 \%$ on average), respectively. In a study that examined the quality and yield of grain-corn varieties, the CF average was $3.54 \%(3.33-4.00 \%)$ with statistically significant differences between varieties 
(Kılınç et al., 2018). In a study that examined the nutrient composition of corn from various countries, Lee et al. (2016) found the average CF content was 3.62\% $(P<0.05)$. Ansah et al. (2012) found $0.60 \% \mathrm{CF}$ in the structure of the corn kernels, and Abubakar et al. (2016) found it was 4.72\%. Kowalik et al. (2013) found the sections of the corn stalk between 15 and $55 \mathrm{~cm}$ and above $55 \mathrm{~cm}$ had CF contents of $0.46 \%$ and $0.76 \%$, respectively, which was higher than the values that were found in the present study. On the other hand, Ming-Yuan et al., (2015) reported that the CF contents of the bottom, middle, and top stalk were 0.66 $0.87 \%, 0.80-1.28 \%$, and $0.86-1.32 \%$, respectively.

Crude cellulose (CC) is the fourth largest constituent of the corn kernel after the carbohydrate, protein, and ether extract (fat) contents. Statistically significant differences existed between the parts of the corn plant, which varied between $2.60 \%$ and $38.96 \%$. ljabadeniyi and Adebolu (2005) and Ullah et al. (2010) found the CC content was $2.07-2.77 \%$ and $0.80-2.32 \%$, respectively. Amodu et al. (2014) found the CC content was between $23.0 \%$ and $27.8 \%$. Vasmani et al. (2016) found it was between $31.65 \%$ and $40.06 \%$. Ansah et al. (2012) found the corn cob was composed of $35.50 \%$ CC, which was confirmed by the $33.3 \%$ found by Abubakar et al. (2016), and 35.03\% and 31.36\%, depending on whether the cutting height was 15 $55 \mathrm{~cm}$ or above $55 \mathrm{~cm}$ (Kowalik et al., 2013). Ming-Yuan et al. (2015) reported that the CC contents of the bottom, middle, and top stalk of the corns were $35.4-42.8 \%, 29.8-35.8 \%$, and $26.7-32.3 \%$, respectively, values which were higher than those found in the present study.

Minerals are an important consideration in animal feeding and in corn (Ahmad et al., 2012; Khan et al., 2014). In terms of proximate analysis of plant materials, minerals are found in the crude ash (CA) fraction. The CA content in the current study was between $0.82 \%$ and $17.90 \%$, and averaged $1.008 \%$. However, the mineral content depends on plant variety (Ullah et al., 2010). Amodu et al. (2014) found the CA content was $4.9-5.1 \%$. Olagunju et al. (2013) revealed that the CA content varied from $31.65 \%$ to $40.06 \%$ in the cob. In another study, it was asserted that the difference in the cutting heights $(15-55 \mathrm{~cm}$ or above $55 \mathrm{~cm})$ affected the average CA contents (8.54 or $8.10 \%$ ) in the corn stalk (Kowalik et al., 2013).

Differences among mean OM, IVOMD, and IVDMD values of component parts of the corn plant were highly significant (Table 4). The OM level was found to be the highest in the cob (94.27\%) and the lowest in the leaf $(74.90 \%)$. In their study, which examined organic matter digestibility (OMD) in some corn varieties, Vasmani et al. (2016) asserted that the OM content of corn was within the range of $91.00 \%$ to $93.69 \%$. However, in the present study, the estimates were more variable among the parts, that is, between $74.90 \%$ and $94.27 \%$. As with the results from the proximate analysis, variations resulted from differences in varieties and lines, maturity level at harvest, and the regions where the corn was grown. Gado et al. (2017) reported that the OM content in the corn stalk was between $75.65 \%$ and $90.27 \%$. Olagunju et al. (2013) stated that the corn cob had $95.34 \%$ OM content. In the current study, the OM content in the shank and husk was observed to be $88.04-89.10 \%$. In a study to determine the nutrient content of the tassel, the OM content was found to be $93.05 \%$ (Li et al., 2014).

Table 4 Mean organic matter content and in vitro digestibilities of organic matter and dry matter of total corn plant and its nine component parts

\begin{tabular}{lccc}
\hline Parts & OM, \% & IVDMD, \% & IVOMD, \% \\
\hline Lower stalk & $88.75^{\mathrm{cd}}$ & $48.13^{\mathrm{e}}$ & $34.90^{\mathrm{d}}$ \\
Central stalk & $87.78^{\mathrm{cd}}$ & $50.50^{\mathrm{c}}$ & $50.07^{\mathrm{b}}$ \\
Upper stalk & $84.75^{\mathrm{e}}$ & $52.19^{\mathrm{c}}$ & $48.28^{\mathrm{bc}}$ \\
Ear stalk & $88.04^{\mathrm{cd}}$ & $49.98^{\mathrm{c}}$ & $47.34^{\mathrm{bc}}$ \\
Ear shuck & $89.10 \mathrm{c}$ & $53.44^{\mathrm{c}}$ & $51.05^{\mathrm{b}}$ \\
Kernels & $91.77^{\mathrm{b}}$ & $79.06^{\mathrm{a}}$ & $78.90 \mathrm{a}$ \\
Cob & $94.27^{\mathrm{a}}$ & $44.43^{\mathrm{d}}$ & $43.41^{\mathrm{c}}$ \\
Leaf & $74.90^{\mathrm{g}}$ & $60.83^{\mathrm{b}}$ & $51.40^{\mathrm{b}}$ \\
Tassel & $80.32^{\mathrm{f}}$ & $52.14^{\mathrm{c}}$ & $45.60^{\mathrm{bc}}$ \\
Entire plant & $87.20^{\mathrm{d}}$ & $51.57^{\mathrm{c}}$ & $48.64^{\mathrm{bc}}$ \\
\hline
\end{tabular}

a-e Within columns means with a common superscript do not differ at $P=0.05$

OM: organic matter, IVDMD: in vitro dry matter digestibility, IVOMD: in vitro organic matter digestibility 
In general, in vitro digestibility is the value calculated from gas measurements taken from the in vitro gas production system. In vitro true digestibility is the value calculated by the rumen simulation technique. In vitro digestibility may be calculated using the 24-hour gas production. On the other hand, IVTD is calculated after 48-hour incubation of the feed in the bags using the rumen simulator. In this study, there was a statistically significant difference between the parts of the corn in terms of IVDMD, which was the highest in the kernel with $79.06 \%$ and the lowest in the lower stalk $38.13 \%$. On the other hand, IVOMD was found to be within the range of $34.90 \%$ to $78.90 \%$. Wattanaklang et al. (2016) stated that the DM and OM of corn stover had digestibilities of $47.71 \%$ and $46.78 \%$, respectively. The same researchers found that DM, CP, EE, CF, and ash contents of corn stover were 99.28, 4.25, 9.64, 32.79, and 1.68\%, respectively. Terler et al., (2019), who investigated corn stover, observed that the potential and effective degradability of $\mathrm{OM}, \mathrm{CP}$, and neutral detergent fibre were influenced significantly by variety and harvest date.

\section{Conclusions}

Morphological parts of the corn plant differ in their nutrient content. Being able to apply these results in animal feeding depends on the ability to separate the plant material into its component parts as is now done in harvesting the grain. Further development of technology may allow the separation of more nutrient rich parts for the corn stover from those parts that are less nutritious. Such technology may be beneficial to livestock production.

\section{Authors' Contributions}

TA contributed to the project idea, design and execution of the study. TA, NÇ, SA and CÇ conducted the laboratory analyses. TA and NÇ supervised the project and wrote the manuscript.

\section{Conflict of Interest Declaration}

There is no conflict of interest.

\section{References}

Abubakar, U.S., Yusuf, K.M., Safiyanu, I., Abdullahi, S., Saidu, S.R., Abdu, G.T. \& Indee, A.M., 2016. Proximate and mineral composition of corn cob, banana and plantain peels. Int. J. Food Sci. Nutr. 1(6), 25-27.

Açar, Z., Öztürk, M. \& Keleş G. 2015. Buğday, mısır ve karabuğday samanları içeren rasyonlarla beslenen dişi tokluların performanslarının belirlenmesi. Türk Tarım-Gıda Bilim ve Tek. Derg. 3(2), 59-62.

Ahmad, K., Khan, Z.I., Shaheen, M. \& Seidavi, A.R., 2012. Dynamics of magnesium, copper and zinc from soil to forages grown in semiarid area in Sargodha, Pakistan. Legume Research 35(4), 294-302.

Ali, Q., Ashraf, M. \& Anwar, F., 2010. Seed composition and seed oil antioxidant activity of maize under water stress. J. American Oil Chem. Soc. 87, 1179-1187.

Aliu, S., Rusinovci, I., Fetahu, S. \& Simeonovska, E., 2012. Genetic diversity and correlation estimates for grain yield and quality traits in Kosovo local maize (Zea mays L.) populations. Acta Agric. Slovenica. 99(2), 121.

Amodu, J.T., Akpensuen, T.T., Dung, D.D., Tanko, R.J., Musa, A., Abubakar, S.A., Hassan, M.R., Jegede, J.O. \& Sani, I., 2014. Evaluation of maize accessions for nutrients composition, forage and silage yields. J. Agric. Sci. 6(4), $178-187$

Ansah, T., Agbolosu, A.A., Teye, G.A., Akwasi, A. \& Opoku-Agyeman, M., 2012. Evaluation of corn cob on the growth performance of grasscutter (Thryonomys swinderianus). Scientific Papers: Anim. Sci. Biotech. 45(1), 7-10.

AOAC (Association of Official Analytical Chemists) 2006. The official methods of analysis of AOAC International. 18th ed. Association of Official Analytical Chemists, Arlington, USA 2, 59-62.

Ayaşan, T., Bozbay, C.K., Aykanat, S. \& Oluk, C.A., 2019. Mısır bitkisinin farklı bölümlerinin besin madde kompozisyonunun tespiti. 2nd International Eurasian Conference on Biological and Chemical Sciences 28-29 June 2019, Ankara/Turkey.

Chea, B., Hout, T., Mob, S., Thenh, K. \& Seng, M., 2015. Nutrient value and palatability for cattle on corn stover silage. International Journal of Environmental and Rural Development (2015) 6-1, 103-107.

Czerkawski, J.W. \& Breckenridge, G., 1977. Design and development of long-term rumen simulation technique (RUSITEC). British J. Nutr. 38, 271-384.

Daud, Z., Hatta, M.Z.M., Kassim, A.S.M., Awang, H. \& Aripin, A.M., 2013. Analysis the chemical composition and fiber morphology structure of corn stalk. Australian J. Basic. Appl. Sci. 7(9), 401-405.

Dumral, Çağlayan, H.N., 2015. Farklı çinko dozlarının mısır (Zea mays L.) çeşitlerinde verim ve tane kalitesi üzerine etkisi. Adnan Menderes Üniversitesi, Fen Bilimleri Enstitüsü, Yüksek Lisans Tezi, Aydın.

FAO. 2014. Global Information and early warning system (GIEWS) (food outlook, food price tool). http://www.fao.org/giews/english/index.htm

Feedipedia 2016. Animal feed resources information system. https://www.feedipedia.org/.

Gado, H.M., Elghandour, M.M.Y., Cipriano, M., Odongo, N.E. \& Salem, A.Z.M., 2017. Rumen degradation and nutritive utilization of wheat straw, corn stalks and sugarcane bagasse ensiled with multi enzymes. J. Appl. Anim. Res. 45(1), 485-489.

Hafez, E.M. \& Abdelaal, K.A., 2015. Impact of nitrogen fertilization levels on morphophysiological characters and yield quality of some maize hybrids (Zea mays L.). Egyptian J. Agron. 37(1), 35-48. 
He, Y., Cone, J.W., Hendriks, W.H. \& Dijkstra, J., 2019. Relationships between chemical composition and in vitro gas production parameters of maize leaves and stems. J. Anim. Physiol. Anim. Nutr. Oct 3. DOI: 10.1111/jpn.13221.

He, Y., Cone, J.W., Hendriks, W.H. \& Dijkstra, J., 2020. Corn stover usage and farm profit for sustainable dairy farming in China. Asian-Australian J. Anim. Sci. DOI: https://doi.org/10.5713/ajas.19.0222.

ljabadeniyi, A.O. \& Adebolu, T.T., 2005. The effect of processing methods on the nutritional properties of ogi produced from three maize varieties. J. Food. Agric. Env. 3, 108-109.

Kalkan, M. \& Sade, B., 2009. Farklı mısır olum grupları ve hasat tarihlerinde verim, tane nemi ile besin değerleri ve aflatoksin düzeylerinin belirlenmesi. Türkiye VIII. Tarla Bitkileri Kongresi, Cilt 1s. 267-271.19-22 Ekim, Hatay.

Karaşahin, M. \& Sade, B., 2011. Effects of different irrigation methods on the grain yield and the yield parameters of hybrid corn (Zea mays L. indentata s.). Uludag Univ. Faculty Agric. J. 25(2), 47-56.

Kanengoni, A.T., Chimonyo, M., Ndimba, B.K. \& Dzama, K., 2015. Potential of using maize cobs in pig diets - A review. Asian Australasian J. Anim. Sci. 28(12), 1669-1679.

Khan, R. \& Dubey, R.B., 2015. Combining ability analysis for nutritional quality and yield in maize (Zea mays L.). The Bioscan. 10(2), 785-788.

Khan, Z.I., Ahmad, K., Mustafa, I., Seidavi, A. R., Hussain, A., Sher, M., Ayube, M., Yousaf, M., Zahoor, A. F., Hussain, G., Annjum, A., 2014. Appraisal of transfer of a few crucial minerals from forage to ruminants: A case study in Pakistan. Journal of the Faculty of Veterinary Medicine Istanbul University (JFVMIU). 40(1), 76-82.

Kılınç, S., Kandemir, Ç. \& Ekin, Z., 2018. Bazı mısır (Zea mays L.) çeşitlerinde verim ve kalite özelliklerinin belirlenmesi. KSÜ Tarım ve Doğa Derg. 21(6), 809-816.

Kowalik, I., Kruczyńska, H. \& Michalski T., 2013. Chemical composition and nutritive value of maize stems depending on the cutting height of plants at harvest. J. Central. Europ. Agric. 14(4), 1244-1253.

Lee, J., Nam, D.S. \& Kong, C., 2014. Variability in nutrient composition of cereal grains from different origins. Springer Plus. 5, 419.

Li, H.Y., Xu, L., Liu, W.J., Fang, M.Q. \& Wang, N., 2014. Assessment of the nutritive value of whole corn stover and its morphological fractions. Asian-Australian J. Anim. Sci. 27(2), 194-200.

Mourtzinis, S., Cantrell, K.B., Arriaga, F.J., Balkcom, K.S., Novak, J.M., Frederick, J.R. \& Karlen, D.L., 2016. Carbohydrate and nutrient composition of corn stover from three southeastern USA locations. Biomass and Bioenergy. 85 (2016) 153e158.

Ming-yuan, L., Gui-yan, W., Wei-li, L., Peng-fei, S., Jing, D., Peng, S. \& Chun-sheng, H., 2015. Yield and quality of maize stover: Variation among cultivars and effects of N fertilization. J. Integ. Agric.14(8), 1581-1587.

Ndukwe, O.K., Edeoga, H.O. \& Omosun, G., 2015. Varietal differences in some nutritional composition of ten maize (zea mays I.) varieties grown in Nigeria. International J. Acad. Res. Reflect. 3(5), 1-11.

Olagunju, A, Onyike, E., Muhammad, A., Aliyu, S. \& Abdullahi, A.S., 2013. Effects of fungal (Lachnocladium spp.) pretreatment on nutrient and antinutrient composition of corn cobs. African J. Biochem. Res. 7(11), 210-214.

Özcan, U. \& Kılıç, Ü., 2018. Farklı katkı maddeleri ilavesiyle peletlenen hasat atığı boş fındıkların kaba yem değerinin belirlenmesi. Selçuk Tarım ve Gıda Bilim. Derg. 32(2), 123-132.

Pordesimo, L. O., Edens, W.C. \& Sokhansanj, S. 2004. Distribution of aboveground biomass in corn stover. Biomass and Bioen. 26(4), 337-343.

SPSS (Statistical Package for the Social Sciences for Windows), 1999. SPPS Inc., Chicago, Illinois, USA.

Sumbo, A.H. \& Victor, I.A., 2014. Comparison of chemical composition, functional properties and amino acids composition of quality protein maize and common maize (Zea mays L.). African J. Food. Sci. Tech. 5(3), 81-89.

Sweley, J.C., Rose, D. \& Jackson, D.C., 2012. Hybrid and environment effects on popcorn kernel physiochemical properties and their relationship to microwave popping performance. J.Cereal. Sci. 55(2), 188-194.

Tandzi, L.N. \& Mutengwa CS., 2020. Estimation of maize (Zea mays L.) yield per harvest area: appropriate methods. Agronomy. 10, 29, DOI:10.3390/agronomy10010029.

Terler, G., Gruber, L. \& Knaus, W.F., 2019. Nutritive value of ensiled maize stover from nine different varieties harvested at three different stages of maturity. Grass Forage Sci. 74, 53-64.

Turkish Grain Board, TMO. 2014. 2014 grain report. 2014.f

Turkish Statistical Institute, 2017. TÜiK, Tarım İstatistikleri. Türkiye İstatistik Kurumu Erişim Tarihi: 06.12.2019, http://www.tuik.gov.tr/UstMenu.do?metod=temelist

Ullah, I., Ali, M. \& Farooqi, A., 2010. Chemical and nutritional properties of some maize varieties grown in NWFP, Pakistan. Pakistan J. Nut. 9(11), 1113-1117.

Variety Registration and Seed Certification Center, 2016. Application. https://www.tarimorman.gov.tr/BUGEM/TTSM/Sayfalar/EN/AnaSayfa.aspx

Vaswani, S., Kumar, R., Kumar, V., Roy, D. \& Kumar, M., 2016. Nutritional and mineral composition of different varieties of normal and high quality protein maize fodder at post-cob stage. Int. J. Sci. Env. Tech. 5(5), 2719-2727.

Wattanaklang, B., Abrar, A. \& Cherdthong, A., 2016. Nutritional value of fermented maize stover as feed for ruminant. Jurnal Peternakan Sriwijaya. 5(1), 44-51. 